\title{
The First Demonstration of Pigeon Circovirus Infection in the Czech Republic Based on Histology and Nested PCR
}

\author{
L. TARAS, O. KUBÍČEK, R. JURANOVÁ, V. JURAJDA
}

Avian and Exotic Animal Clinic

University of Veterinary and Pharmaceutical Sciences, Brno, Czech Republic

Received November 28, 2002

Accepted November 29, 2003

\begin{abstract}
Taras, L., O. Kubíček, R. Juranová, V. Jurajda: The First Demonstration of Pigeon Circovirus Infection in the Czech Republic Based on Histology and Nested PCR. Acta Vet. Brno 2003, 72: 577-582.

The aim of the study was to demonstrate presence of pigeon circovirus in the Czech Republic. Squabs suspected of being infected with pigeon circovirus were selected based on clinical and pathological testing. To reach the diagnosis, a method of proving the pigeon circovirus DNA based on nested polymerase chain reaction (PCR) was developed. The specificity of the PCR reaction was verified using PCR product sequencing. A sequence of PCR products was compared against pigeon circovirus sequences published so far. The comparison has confirmed the highest relation between the isolate South Moravian 1 detected by us and the North-Irish isolate 7050. The trial has thus brought an ultimate proof of the presence of pigeon circovirus in the Czech Republic. The nested PCR method for proving pigeon circovirus was developed and a new isolate of the virus was detected.

PiCV, PCR, pigeon, circovirus
\end{abstract}

Circoviruses are held to be the smallest animal viruses yet known. The genome consists of single-stranded (ss) circular DNA sized $1.7-2.3 \mathrm{~kb}$. The particules are nonenveloped, round-to-icosahedral, with diameters ranging from 15 to $25 \mathrm{~nm}$ (Todd et al. 2001).

Pigeon circovirus ( $\mathrm{PiCV}$ ) or columbid circovirus $(\mathrm{CoCV})$, along with porcine circovirus, parrot circovirus, goose circovirus, and most recently, also canary circovirus, is part of Circovirus genus (Todd et al. 2001; Phenix et al. 2001). Circoviral infection in pigeons was first recorded in the USA (Woods et al. 1993). It has so far been reported in the USA, Canada, Great Britain, the Federal Republic of Germany, Belgium, Italy, and France (Woods et al. 1994; Smyth et al. 1995; Soike 1997; Pare et al. 1999; Tavernier et al. 2000; Colleti et al. 2000; Abadie et al. 2001).

The disease characterized by non-specific clinical signs affects young pigeons up to 6 months of age. Clinical symptoms of secondary illnesses due to viral, bacterial, parasitic, or mycotic infections can be observed depending on the health status of the flock and the zoohygienic conditions of the farm.

Typical pathological findings due to circoviral infection are atrophy of the bursa of Fabricius (BF) and thymus. Lymphatic follicules of the BF are tested for the presence of intracytoplasmatic botryoid inclusions using a pathohistological method. Electron microscopy and a method based on a specific DNA sequence demonstration can be used to prove the presence of the circovirus (Soike et al. 2001).

All attempts to isolate pigeon circovirus from chicken embryos, chicken kidney tissue cultures or chicken fibroblasts have failed so far (Woods and Shiv a pras ad 1997). Recent proofs of PiCV have been based on the presence of viral DNA using in situ hybridisation or, more recently, nested PCR (Abadie et al. 2001; S myth et al. 2001; Soike et al. 2001).

Address for correspondence:

MVDr. Ladislav Taras

Avian and Exotic Animal Clinic

of Veterinary and Pharmaceutical Sciences, Brno

Palackého 1-3, 612 42 Brno, Czech Republic
Phone: +420541562820

Fax: +420 54156238

http://www.vfu.cz/acta-vet/actavet.htm 
The aim of this study was to demonstrate presence of pigeon circovirus in the Czech Republic using the nested PCR method.

\section{Material and Methods}

Pigeons

The sample included squabs examined at the Avian and Exotic Animal Clinic. The 12 squabs were from breeding flock A, B, and C.

Breeding flock A

A breeding flock of Moravian ostriches with about 150 pigeons in an outside/inside aviary with a fixed washable floor. Salmonella typhimurium var. copenhagen, trichomonosis, and cocidiosis were diagnosed in the breeding flock. Respiratory problems and diarrhoea were the most frequent clinical signs observed. High morbidity and mortality were characteristic especially of squabs. Perished squabs had atrophy of the thymus and the BF and their respiratory systems showed different pathological findings including rhinitis, aerosacculitis, and necrotic foci in the oropharynx.

\section{Breeding flock B}

A mixed breeding flock of meat (giant) and homing pigeons. Squabs sent for an examination were found to suffer from respiratory problems of which conjunctivis, rhinitis, and sinusitis were the dominant ones. Some squabs were heavily infected with trichomonads; chronic cocidiosis was diagnosed. Pathoanatomical examination revealed severe oedema in the paranasal cavities of the head and aerosacculitis of different severity; most squabs shared atrophy of the BF and thymus. Bacteriological examination resulted in isolating Yokenella regensburgei from choanal swab.

Breeding flock C

A breeding flock of homing pigeons vaccinated against paramyxovirosis as part of prevention, where Salmonella typhimurium var. copenhagen was detected. Therapy based on susceptibility to antibiotics failed. One of the squabs showed nervous signs - torticollis and circling movement.

Within the trial, 7 squabs from breeding flock A, 3 squabs from breeding flock B, and 2 squabs from breeding flock $\mathrm{C}$ were examined.

The negative controls were 2 clinically healthy squabs from a breeding flock without health problems.

Bacteriological examination

Organs from perished pigeons affected with macroscopic alterations were sent for bacteriological examination to the Department of Microbiology and Immunology of the University of Veterinary and Pharmaceutical Sciences, Brno.

Parasitological examination

Caudal segments of the intestine of perished squabs were subjected to coprological examination. The use of the flotation technique revealed the presence of Eimeria sp. Crop swabs of live squabs showed Trichomonas gallinae infection of varying intensity.

Histological xamination

For the purposes of histopathological examination, the bursae of Fabricius of the perished squabs were taken and fixated in a $10 \%$ neutral water solution of formaldehyde and then processed by the common method of embedding into paraffin, and stained with hematoxyline and eosin.

Polymerase chain reaction

Frozen samples of the bursa of Fabricius were tested. DNA isolation was performed with the help of the Invisorb Spin Tissue Mini Kit isolation set (Invitek, Berlin). The first PCR reaction included $2 \mu 1$ of isolated DNA, $7 \mu$ lof sterile redistilled water, and $1 \mu \mathrm{l}$ of primers $25 \mathrm{pmol} / \mathrm{l}$ and $10 \mu \mathrm{l}$ Sigma Red Taq PCR Mix with $\mathrm{MgCl}_{2}\left(\mathrm{Sigma}_{\mathrm{St}} \mathrm{St}\right.$ Louis). To prove the presence of PiCV DNA, primers from the C 1 ORF (open reading frame) area were used. The first PCR included primers F 330 (bases 1282 to 1299, 5' - TGAGGGTGGTCCAAGCAA - 3') and B 331 (bases 1893 to $1874,5^{\prime}$ - ACAGGAGGAGTAGCCGTATT - 3’) as described above (Soike et al. 2001). The reaction took place at $94{ }^{\circ} \mathrm{C}$ for $4 \mathrm{~min}$, then at $94{ }^{\circ} \mathrm{C}$ for $30 \mathrm{~s}$, at $49{ }^{\circ} \mathrm{C}$ for $20 \mathrm{~s}$, at $72{ }^{\circ} \mathrm{C}$ for $45 \mathrm{~s}$, for 35 times and then at $72{ }^{\circ} \mathrm{C}$ for $8 \mathrm{~min}$. The second PCR included PiCV-specific primers from within an amplified area based on the sequences described above (Mankertz et al. 2000; Todd et al. 2001), Circo2Sn66 5'GGGTCTGGTTGGGGTTGCAGG-3' and Circo2Asn566 5' - CTTCCGCCTACGTCGCAAGGAC - 3’' (see Table 1). Their specificity was verified by comparing them against sequences obtained from the GenBank at NCBI using the BLAST (Basic Local Alignment Search Tool) (Altschul et al. 1990). 
The reaction dilution was prepared from $1 \mu \mathrm{lmix}$ of both $25 \mathrm{pmol} / \mathrm{primers}, 9 \mu \mathrm{l}$ of redistilled sterile water, $10 \mu \mathrm{l}$ Sigma Red Taq PCR Mix, and $1 \mu \mathrm{l}$ of amplificates obtained from the first PCR. The second reaction took place at $94{ }^{\circ} \mathrm{C}$ for $2 \mathrm{~min}$, then at $94{ }^{\circ} \mathrm{C}$ for $30 \mathrm{~s}$, at $65^{\circ} \mathrm{C}$ for $20 \mathrm{~s}$, at $72{ }^{\circ} \mathrm{C}$ for $30 \mathrm{~s}$ for 35 times and then at $72{ }^{\circ} \mathrm{C}$ for $8 \mathrm{~min}$. The reaction was evaluated on $1.5 \%$ agarose gel stained with ethidiumbromide. The size of the amplification product was compared against the DNA mass marker 2 - Log DNA Ladder (New England Biolabs). The reaction was qualified as positive in case the presence of a fragment sized $522 \mathrm{bp}$ was detected. Its specificity was verified by sequencing.

Table 1

Primers used for PiCV detection

\begin{tabular}{|l|l|l|}
\hline Primer & Sequence & Locus in the genome \\
\hline F 330 & TGAGGGTGGTCCAAGCAA & $1282-1299^{*}$ \\
\hline B 331 & ACAGGAGGAGTAGCCGTATT & $1893-1874^{*}$ \\
\hline Circo2Sn66 & GGGTCTGGTTGGGGTTGCAGG & $1348-1368$ \\
\hline Circo2Asn566 & CTTCCGCCTACGTCGCAAGGAC & $1868-1846$ \\
\hline
\end{tabular}

* (Soike et al. 2001)

Sequencing (verification of PCR product specificity)

The sequencing of PCR product nucleotides was performed in both directions with the help of capillary electrophoresis using a laser-induced phosphorescence detector and an automated genetic analyser (ABI PRISM 310 Genetic Analyser, Perkin Elmer) in the Laboratory of Function Genomics and Proteomics, Faculty of Science, Masaryk University, Brno. The sequencing used the Circo2Sn66 and Circo2Asn566 primers and dye terminators.

\section{Results}

Of the 12 squabs from Breeding flocks A, B, and C included in the trial on the basis of suspicion of circoviral infection, 10 had pathological findings in histological examination. Lymphatic follicules displayed follicule shape alterations, lymphocytodepletion of varying degree, and presence of cysts of varying size containing homogenous substance. Cells located in the centre of the follicules were found to contain large aggregates of intracytoplasmatic basofil inclusions (see Plate XIV, Fig. 1).

The nested PCR confirmed the presence of circoviral DNA in squabs with positive histological examination results. The remaining two squabs from the breeding flocks suspected of circoviral infection whose results of histological examination were negative, were found positive in terms of the presence of viral DNA, too.

The samples of BF of the two squabs from the healthy breeding flock neither showed histological alterations nor a specific PCR product was detected in them (see Table 2).

Table 2

Comparison of histological examination and nested PCR results

\begin{tabular}{|c|c|c|c|c|c|c|c|c|c|c|c|c|c|c|}
\hline & \multicolumn{7}{|c|}{ Flock A } & \multicolumn{3}{|c|}{ Flock B } & \multicolumn{2}{|c|}{ Flock C } & \multicolumn{2}{|c|}{ Controls } \\
\hline & 1 & 2 & 3 & 4 & 5 & 6 & 7 & 8 & 9 & 10 & 11 & 12 & 13 & 14 \\
\hline Histology BF & + & + & + & + & - & + & + & - & + & + & + & + & - & - \\
\hline Nested PCR & + & + & + & + & + & + & + & + & + & + & + & + & - & - \\
\hline
\end{tabular}

The PCR product sequence of one of the squabs (Breeding flock A, sample No. 3, South Moravian) (GenBank accession number AY461810) was established and subsequently compared against the sequences published so far (see Fig. 3). This revealed a 93\% homology with the isolate 7050 and a $92 \%$ homology with the isolate 9030 described by Todd et al. (2001) and a 91\% homology with the sequence AF252610 described by Mankertz et al. (2000). 
Fig. 3

Comparison of the sequence South Moravian 1 with the sequences of pigeon circovirus published so far

ALIGNED SEQUENCE PRINTOUT

$\begin{array}{rllll}\text { Reference molecule:SM 1 } & 1-485 & (485 \mathrm{bps}) & \text { Homology } \\ \text { Sequence } & 2: \text { AJ298230 } & 1-485 & (485 \mathrm{bps}) & 938 \\ \text { Sequence } & 3: \text { AJ298229 } & 1-485 & (485 \mathrm{bps}) & 928 \\ \text { Sequence } & 4: \text { AF252610 } & 1-485 & (485 \mathrm{bps}) & 918\end{array}$
SM 1
AJ298230
AJ298229
AF252610
1) AACAGAATGCGAGCCCATAGTGATTAACTTTCTGGGGAAACAAGCTGTTG

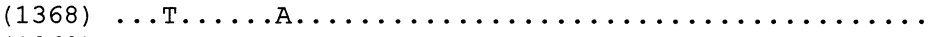
(1369) ‥ . . . . . .

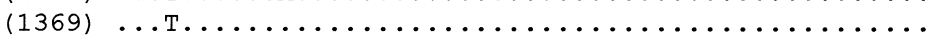
SM 1
AJ298230
( 51) CCTGATACCTGCAGTGGTATCCACTGGTTCCTCCCTGAGAACCAGGTTGC
AJ298229

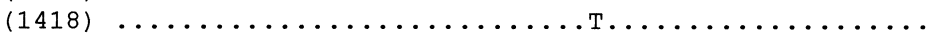
AF252610

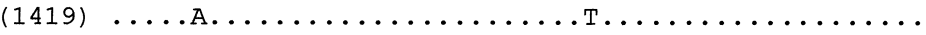

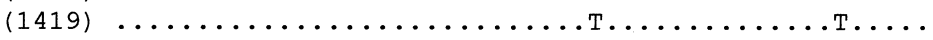
SM 1
( 101 ) TGCCGACTGGTTTGCCGTGGCTAGGTCAGCGATTGTGAGTTGAGGTCTTG
AJ298230
AJ298229

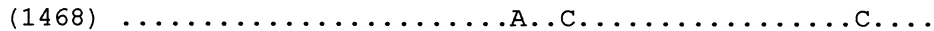

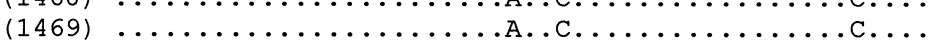
AF252610

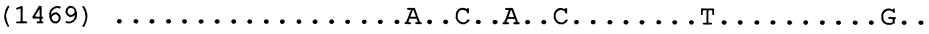
SM 1
( 151 ) GCCTTATGAGGCGTTTGAAGCCTTTTCTCAAATCCCATTTTCTGGCTCCG
AJ298230
AJ298229
AF2 2610

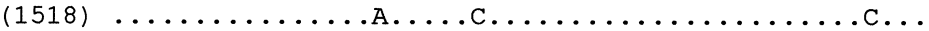

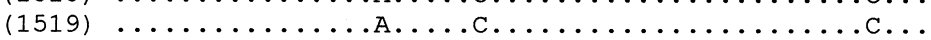

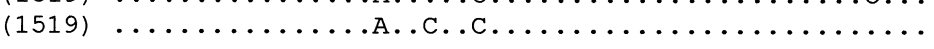
SM 1
AJ298230
AJ298229
( 201) TCAAAGTCCATGAGGGGGTCGTCGCCCAAGTCAGTTTGGCCTTGAAAGGT

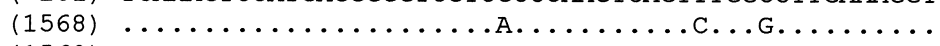
AF2 52610

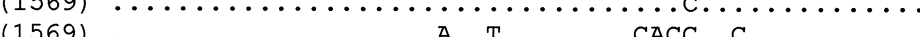
SM 1
AJ298230
AJ298229
AF 252610
( 251) TTTCAGCCTGGCATCATACATCGGGACTGTGTGCCCGAATCCTTTCCAGG

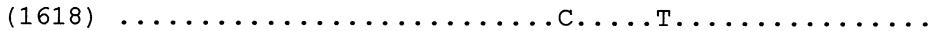

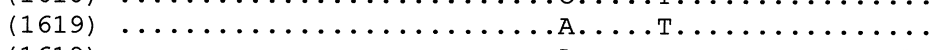
SM 1
AJ298230
AJ298229
A. . . . . .
( 301) TCGTGATGTCAACACCCAGTGGTCTCATTTCCACCTTCACTAATGCTATC
$(1668) \quad \ldots \ldots \ldots \ldots \ldots$ T. . . . . . . . . . . . . . .
$(1669) \quad \ldots \ldots \ldots \ldots \ldots$. . . . . . . . . . . . . . . . .

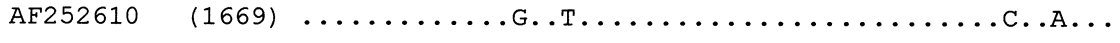
SM 1
( 351) TGATAGTCCTCAAATGGGACGTGTAGCGTTGGAGCGTTGAGACCAACCGT
AJ298230
AJ298229

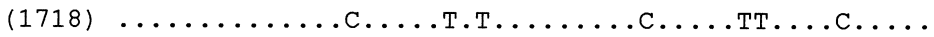
AF2 52610
$(1719) \quad \ldots \ldots \ldots \ldots$. . . . . . . . . . . . . . . .
SM 1
(1719) $\ldots \ldots \ldots \ldots \ldots$. . . TC................
AJ298230
( 401$)$ CAGTACATCCTCCAGTTTGAATGTAAAGAATCCAGTCCCCAAATTGAAAT
AJ298229
(1768) G..................T.T.............
AF252610

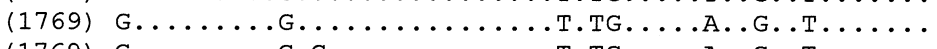

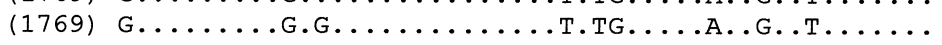
SM 1
( 451) CATTGGTCGCCTGCGTCAAGGTTATCTTGTCCTTG
AJ298230

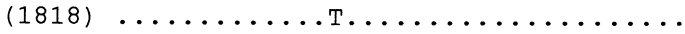

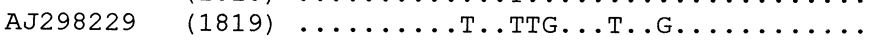
AF252610

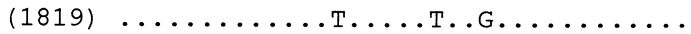




\section{Discussion}

Circovirus infection in pigeons is a recently described infectious disease accompanied by immunosuppression of the affected birds.

Due to the fact that the illness has no characteristic clinical signs and squabs die due to secondary infections, the disease was diagnosed as late as in the beginning of the 1990s. The proof of the infection was made possible by the development of specific diagnostic techniques for detection of the circovirus such as electron microscopy of lymphatic organs, DNA hybridisation, and especially the more recent PCR (Woods et al. 1994; Soike et al. 2001).

Despite the fact that circovirus infection had not been diagnosed in pigeons in the Czech Republic, we had kept encountering breeding flocks of pigeons showing some signs of the infection.

Needing to find positive animals in order to be able to establish diagnostic techniques, we focused on breeding flocks suspected of circoviral infection. The screening focused especially on squabs with macroscopic atrophy of the bursa of Fabricius. This is the reason why the incidence of histological findings is higher than the figures reported by Soike et al. (2001) and S myth et al. (2001). Drawing on the fact that it is in this organ that inclusions are reported most often (Shivapras ad et al. 1994) we chose the bursae of Fabricius for histological examination. As the highest amount of viral DNA was detected, using in situ hybridisation, in the bursae of Fabricius, too (Abadie et al. 2001; S myth et al. 2001), the same organ was chosen to be subjected to PCR analysis.

New primers Circo2Sn66 and Circo2Asn566 with an annealing temperature significantly higher than that of the method used before (Soike et al. 2001) were chosen for the purposes of the second reaction as we aimed at achieving a higher specificity and sensitivity of the reaction.

Comparing the sequence of our amplified product with available sequences using the BLAST alignment tool, we proved the highest homology with pigeon circoviruses, bringing thus an ultimate proof of the pathogen. The homology ranging between $91 \%$ and 93\% with the sequences published so far corresponds approximately to the differences between isolates from Northern Ireland and Germany. This level of homology suggests a relatively great variability of the virus. Although the highest homology detected $(93 \%)$ was with the North-Irish isolate 7050, the fact alone does not entitle us to deriving the origin of the Czech isolate from it.

The paper is the first report of the incidence of pigeon circovirus in the Czech Republic.

\section{První průkaz infekce holubím cirkovirem v České republice potvrzený histologicky a pomocí nested PCR}

Cílem práce bylo potvrdit přítomnost holubího cirkoviru v České republice. Na základě klinického a patologického vyšetření byla vybrána holoubata s podezřením na infekci holubím cirkovirem. Pro potvrzení této diagnózy byla vyvinuta metoda průkazu přítomnosti DNA holubího cirkoviru metodou nested polymerase chain reaction $(\mathrm{PCR})$. Specifita $\mathrm{PCR}$ reakce byla ověřena sekvenací PCR produktů. Sekvence PCR produktu byla porovnána s dosud publikovanými sekvencemi holubího cirkoviru. Toto porovnání potvrdilo nejvyšší příbuznost námi detekovaného izolátu South Moravian 1 se severoirským izolátem 7050. Jednoznačně tak byla prokázána př́ítomnost holubího cirkoviru v České republice. Byla vyvinuta modifikovaná metoda nested PCR průkazu holubího cirkoviru a byl detekován nový izolát tohoto viru. 


\section{Acknowledgment}

The study received support from the research project of the Ministry of Education, Youth, and Sports of the Czech Republic (No. 161700002). The first author (L.T.) would like to thank Dr. D. Soike (LVL Potsdam, Germany) for his valuable advise.

\section{References}

ABADIE, J, NGUYEN, F, GROIZELEAU, C, AMENNA, N, FERNARDEZ, B, GUERREAUD, C, GUIGAND, L, ROBART, P, LEFEBVRE, B, WYERS, M 2001: Pigeon circovirus infection: pathological observations and suggested pathogenesis. Avian Pathol 30: 149-158

ALTSCHUL, SF, GISH, W, MILLER, W, MYERS, EW, LIPMAN, DJ 1990: Basic local alignment search tool. J Mol Biol 215:403-410

COLETTI, M, FRANCIOSINI, MP, ASDRUBALI, G, PASSAMONTI, F 2000: Atrophy of the primary lymphoid organs of meat pigeons in Italy associated with circovirus-like particles in the bursa of Fabricius. Avian Dis 44: 454-459

PHENIX, KV, WESTON, JH, YPELAAR, I, LAVAZZA, A, SMYTH, JA, TODD, D, WILCOX, GE, RAIDAL, SR 2001: Nucleotide sequence analysis of a novel circovirus of canaries and its relationship to other members of the genus Circovirus of the family Circoviridae. J Gen Virol 82: 2805-2809

PARE, J, BRASH, ML, HUNTER, DB, HAMPSON, RJ 1999: Observations on pigeon circovirus infection in Ontario. Can Vet J 40: 659-662

SMYTH, JA, CARROLL, BP 1995: Circovirus infection in European racing pigeons. Vet Rec 136: 173-174

SOIKE, D 1997: Circovirus infection in pigeons. Tierarztl Prax 25: 52-54

SOIKE, D, HATTERMANN, K, ALBRECHT, K, SEGALES, J, DOMINGO, M, SCHMITT, C, MANKERTZ, A 2001: A diagnostic study on columbid circovirus infection. Avian Pathol 30: 605-611

SHIVAPRASAD, HL, CHIN RP, JEFFREY JS, LATIMER KS, NORDHAUSEN RW, NIAGRO FD, CAMPAGNOLI RP 1994: Particles resembling circovirus in the bursa of Fabricius of pigeons. Avian Dis. 38: 635-641

TAVERNIER, P, DE HERDT, P, THOONEN, H, DUCATELLE, R 2000: Prevalence and pathogenic significance of circovirus-like infections in racing pigeons (Columba livia). Vlaams Diergen Tijds 69: 338-340

TODD, D, WESTON, JH, SOIKE, D, SMYTH, JA 2001: Genome sequence determinations and analyses of novel circoviruses from goose and pigeon. Virology 286: 354-362

WOODS, LW, LATIMER, KS, BARR, BC, NIAGRO, FD, CAMPAGNOLI, RP, NORDHAUSEN, RW, CASTRO, AE 1993: Circovirus-like infection in a pigeon. J Vet Diagn Invest 5: 609-612

WOODS, LW, LATIMER, KS, NIAGRO, FD, RIDDELL, C, CROWLEY, AM, ANDERSON, ML., DAFT, BM, MOORE, JD, CAMPAGNOLI, RP, NORDHAUSEN, RW 1994: A retrospective study of circovirus infection in pigeons - 9 cases (1986-1993) J Vet Diagn Invest 6: 156-164 
Plate XIV

Taras L. et al.: The First Demonstration...pp. 577-582

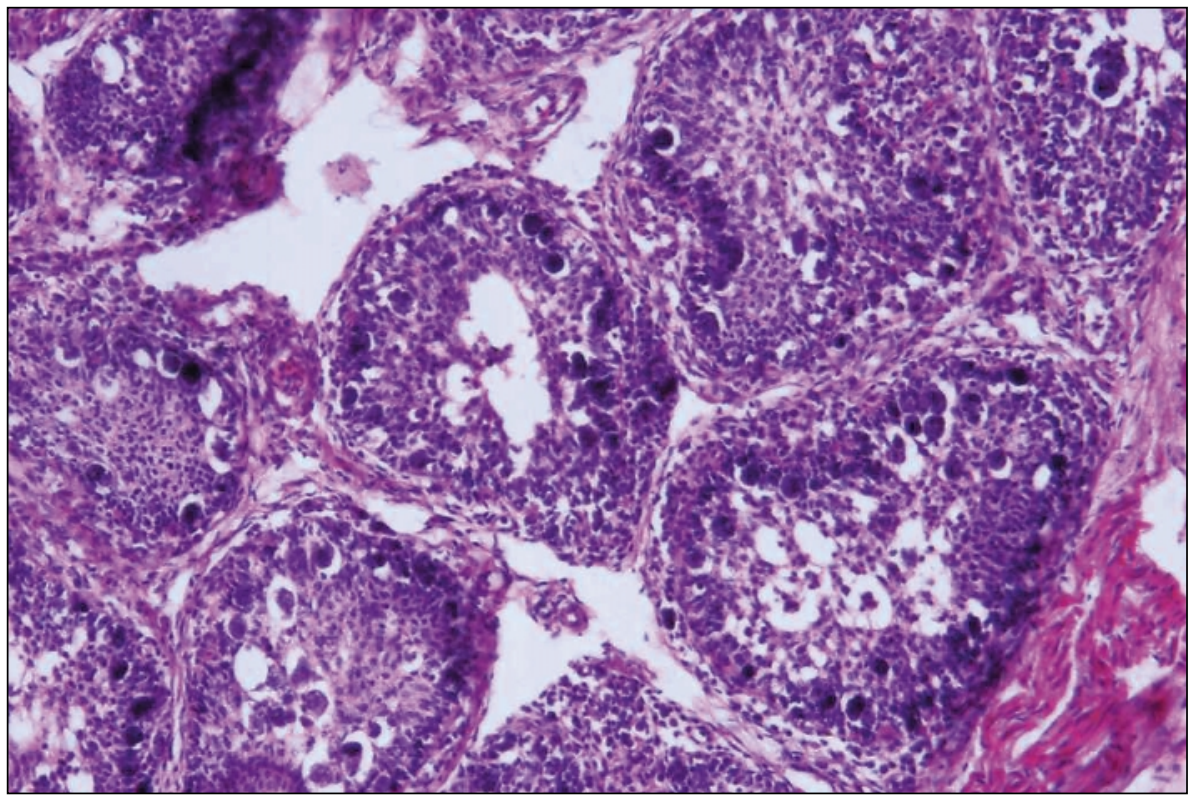

Fig. 1. The bursa of Fabricius of a squab with numerous circoviral inclusion bodies in follicular cells.

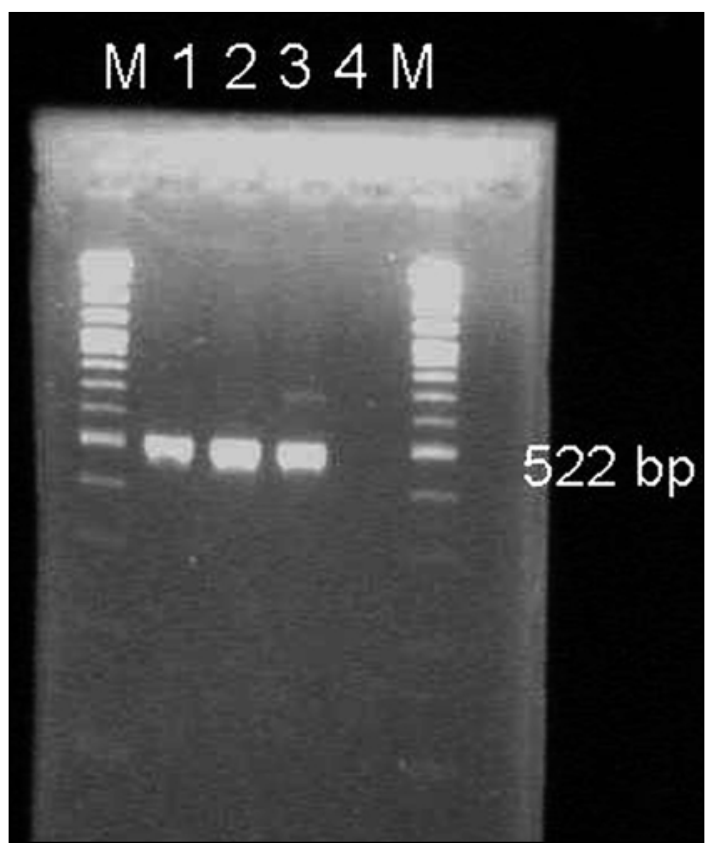

Fig. 2. PiCV DNA detection in pigeon BF samples using nested PCR. Electrophoresis on 1.5\% agarose gel stained with ethidiumbromide. Lane M - mass marker $2-\log$ DNA Ladder (New England Biolabs), lane 1 - sample from flock A, lane 2 - sample from flock B, lane 3-sample from flock C, lane 4-control sample. 